\title{
UPACARA PERKAWINAN ADAT SUNDA DI KECAMATAN CICALENGKA KABUPATEN BANDUNG
}

\author{
Oleh Aam Masduki \\ Balai Pelestarian Sejarah dan Nilai Tradisional Bandung \\ Jln. Cinambo No. 136 Ujungberung Bandung \\ Email:aammasduki@gmail.com
}

Naskah diterima:10 Juni 2010

Naskah disetujui:6 September 2010

\begin{abstract}
Abstrak
Upacara perkawinan adat Sunda lazimnya disebut Upacara Nikahkeun (dalam bahasa Sunda halus) atau Ngawinkeun (dalam bahasa Sunda kasar), yang artinya menikahkan atau mengawinkan. Nikah atau kawin mengandung arti bersatunya dua insan (laki-laki dan perempuan) yang disahkan secara agama dan oleh negara untuk hidup sebagai suami istri. Atau dengan kata lain, nikah adalah kesepakatan dua insan yang berlainan jenis untuk mengadakan ikatan guna membentuk keluarga atau rumah tangga untuk mencapai keluarga yang sakinah, mawadah dan warohmah. Tujuan dari penelitian ini yaitu untuk mendokumentasikan salah satu jenis upacara tradisional yang ada di Kabupaten Bandung Provinsi Jawa Barat agar orang Sunda, terutama generasi mudanya dapat mengetahui, memahami, dan menyayangi budaya sendiri. Dalam penelitian ini metode yang digunakan adalah metode deskriptif dengan pendekatan kualitatif. Adapun teknik pengumpulan data yang dipergunakan adalah observasi, wawancara, dan studi kepustakaan. Dari hasil pengkajian yang dilakukan oleh penulis, dapat disimpulkan bahwa upacara-upacara baik yang dilakukan sebelum acara pernikahan (Ngalamar, Ngeuyeuk Seureuh, Seserahan) maupun setelah pernikahan (Sawer, Ninjak Endog, Buka Pintu, Ngunduh Mantu) masih tetap dilakukan oleh masyarakat di Kabupaten Bandung.
\end{abstract}

Kata kunci: upacara tradisional, perkawinan, Sunda.

\begin{abstract}
This research is a case study about Sundanese traditional wedding ceremony that implemented in Kecamatan Cicalengka, Kabupaten Bandung. The purpose of the research is to make a documentation of it. It is very important to make such a documentation in order to make young generation know and appreciate their own culture. A qualitative method was conducted and the data were collected through observation, interview, and bibliographical study. The author came into conclusion that the people of Cicalengka remain preserving their traditional wedding ceremony, either the one that must be done before the akad nikah (the wedding pledge) or the ones that following it.
\end{abstract}

Keywords: traditional ceremony, marriage, Sundanese. 


\section{A. PENDAHULUAN}

Upacara adalah suatu kegiatan pesta tradisional yang diatur menurut tata cara adat atau hukum yang berlaku dalam masyarakat dalam rangka memperingati suatu peristiwa. Beberapa daerah di Kabupaten Bandung, Provinsi Jawa Barat hingga kini masih melangsungkan adat istiadat yang merupakan warisan leluhurnya, seperti kegiatan upacara tradisional. Untuk menandai sesuatu maka orang memberi tanda yang mengandung ciri-ciri dari suatu itu, tanda ini biasa disebut dengan nama (Rajiman, 1984: 60).

Upacara tradisional merupakan salah satu wujud kebudayaan dan berkaitan dengan berbagai nilai, sehingga mempunyai arti yang sangat penting bagi kehidupan masyarakat pendukungnya. Arti penting tersebut tampak dalam kenyataan bahwa melalui upacara-upacara tradisional dapat diperkenalkan nilai-nilai luhur budaya bangsa. Selain itu juga dapat mengungkap makna simbolik yang terkandung di dalamnya untuk memahami eksistensi atau keberadaan upacara tradisional sebagai satu keseluruhan.

Kebudayaan adalah keseluruhan sistem gagasan, tindakan dan hasil karya manusia dalam rangka kehidupan masyarakat yang dijadikan milik diri manusia dengan belajar (Koentjaraningrat, 1980:193). Adapun wujudnya mencakup tiga hal yaitu ideide, aktivitas, dan benda-benda hasil kebudayaan. Pada umumnya kebudayaan bersifat adaptif karena melengkapi manusia dengan cara-cara penyesuaian diri pada kebutuhankebutuhan yang bersifat fisik maupun nonfisik (Ember dan Ember dalam TO Ihromi, 1980). Kebiasaan atau kelakuan terpola yang ada dalam masyarakat tertentu merupakan penyesuaian masyarakat itu terhadap lingkungannya, tetapi cara penyesuaian seperti itu tidak berarti mewakili semua cara penyesuaian yang mungkin diadakan oleh masyarakat lain dalam kondisi yang sama. Hal tersebut menyebabkan setiap masyarakat mempunyai pola kebudayaan yang khas dan dapat membedakannya dengan masyarakat yang lain.

Upacara keagamaan dalam kebudayaan suatu suku bangsa biasanya merupakan unsur kebudayaan yang tampak paling lahir (mudah dikenali atau dilihat). Masalah asal mula dari suatu unsur universal seperti religi, artinya masalah mengapa manusia percaya kepada adanya suatu kekuatan gaib yang dianggapnya lebih tinggi daripadanya, dan mengapa manusia itu melakukan berbagai hal dengan cara-cara yang beraneka warna untuk berkomunikasi dan mencari hubungan dengan kekuatan-kekuatan tadi. Semua aktivitas manusia yang bersangkutan dengan religi berdasarkan atas suatu getaran jiwa biasanya disebut emosi keagamaan atau religious emotion. Emosi keagamaan ini biasanya pernah dialami oleh setiap manusia, walaupun getaran emosi itu mungkin hanya berlangsung beberapa detik saja. Emosi keagamaan itulah yang mendorong orang melakukan tindakan-tindakan yang bersifat religi (Koentjaraningrat, 1980: 391).

Tujuan penelitian upacara perkawinan adat Sunda ini adalah sebagai berikut :

1. Untuk mendokumentasikan salah satu jenis upacara tradisional yang ada Kabupaten Bandung, Provinsi 
Jawa Barat dalam rangka melestarikan beragam upacara tradisional.

2. Supaya orang-orang Sunda sendiri, terutama generasi muda dapat mengetahui maksud penyelenggaraan upacara adat bangsanya sendiri.

3. Untuk memperkaya data budaya yang ada di Balai Pelestarian Sejarah dan Nilai Tradisional Bandung.

Sesuai dengan tujuan dan judul penelitian, "Kajian Nilai Budaya tentang Upacara Perkawinan Adat Sunda", maka ruang lingkup penelitian ini dibagi dua, yaitu ruang lingkup wilayah dan ruang lingkup materi. Ruang lingkup wilayah penelitian ini adalah masyarakat di Kecamatan Cicalengka, Kabupaten Bandung, Provinsi Jawa Barat. Sedangkan lingkup materi mengenai penelitian ini adalah :

a. Upacara sebelum menikah meliputi :

1) Upacara Ngalamar 'melamar'

2) Upacara Ngeuyeuk Seureuh

3) Upacara Seserahan

b. Upacara sesudah akad nikah meliputi :

1) Upacara

Munjungan/Sungkeman

2) Upacara Nincak Endog 'telur'

3) Upacara Buka Pintu

4) Upacara Huap Lingkung

5) Upacara Sawer

6) Upcara Meuleum Harupat

7) Upacara Ngalengkahan Pakara

8) Upacara Ngunduh Mantu.

Pada dasarnya pendekatan penelitian untuk masalah sosial budaya ada dua, yaitu pendekatan kuantitatif dan metode kualitatif. Adapun metode yang dipergunakan dalam penelitian ini yaitu metode kualitatif, mendasarkan pada yang bukan angka atau penjelasan-penjelasan secara detail dan mendalam. Untuk teknik pengumpulan data di lapangan, yang dipergunakan adalah observasi, wawancara, dan studi kepustakaan.

\section{B. HASIL DAN BAHASAN}

\section{Upacara Sebelum Menikah}

Masyarakat di Kecamatan Cicalengka, Kabupaten Bandung yang dijadikan lokasi penelitian khususnya dalam upacara adat perkawinan tidak berbeda dengan masyarakat Sunda di Jawa Barat pada umumnya. Demikian juga dalam upacara yang dilaksanakan sehubungan dengan adat perkawinan. Walaupun ada perbedaan, mungkin perbedaan itu terdapat dalam segi-segi tertentu yang bersifat lokal, baik yang berkaitan dengan kondisi dan keadaan lingkungan maupun kebiasaankebiasaan dan kepercayaan masyarakat di masing-masing daerah.

\section{a. Ngalamar (Melamar)}

Ngalamar (melamar), bisa jadi asal kecap dari ngalemar atau nyeureuhan, artinya menyimpan omongan. Ngalamar, nanyaan atau nyeureuhan yaitu nanyaan perempuan mau atau tidaknya untuk dikawinkan dengan lelaki yang disenanginya. Pada umumnya lelaki yang akan melamar, tidak sendiri tapi didampingi pihak orang tua dengan keluarganya. Kunjungan orang tua jejaka adalah untuk meminang atau melamar si gadis kepada orang tuanya. Lamaran biasanya dilaksanakan oleh orang tua calon pengantin beserta keluarga dekat, disertai seseorang yang berusia lanjut 
sebagai pemimpin upacara lamaran dengan membawa lemareun atau sirih pinang komplit, uang, seperangkat pakaian wanita sebagai pameungeut (pengikat). Cincin tidak mutlak harus dibawa. Jika dibawa, biasanya berupa cincin meneng melambangkan kemantapan dan keabadian. Orang tua jejaka dan keluarga dengan wakilnya kepada sesepuh yang sudah ahli dalam acara melamar dalam kunjungan tersebut, wakil dari pihak keluarga jejaka, mengutarakan maksud dan tujuannya kepada orang tua si gadis, bahwa maksud dan tujuan datang kepada orang tua si gadis, yaitu ingin meminang anaknya. Dengan harapan orang tua si gadis mau menerima lamaran orang tua jejaka, untuk menikah dengan anaknya. Orang tua si gadis menerima lamaran orang tua si jejaka, untuk menikahkan anaknya masing-masing. Sesudah lamaran orang tua jejaka diterima oleh pihak orang tua gadis, dilanjutkan kemudian membahas mengenai rencana waktu tanggal dan bulan pelaksanaan pernikahannya. Sebagai acara penutup dalam ngalamar ini, si pelamar memberikan uang sekadarnya kepada orang tua si gadis, sebagai tanda panyangcang atau pengikat, kadang-kadang dilengkapi pula dengan sirih pinang selengkapnya disertai kue-kue dan buah-buahan.

\section{b. Ngeuyeuk Seureuh}

Upacara Ngeuyeuk Seureuh. Ngeuyeuk Seureuh: artinya mengerjakan dan mengatur sirih serta mengaitngaitkannya. Upacara ini dilakukan sehari sebelum hari perkawinan, yang ikut melaksanakan upacara ini adalah kedua calon pengantin, orang tua calon pengantin dan para undangan yang telah dewasa. Upacara dipimpin oleh seorang pemandu. Adapun barangbarang yang diperlukan sebagai perlengkapan untuk upacara ini seperti sirih beranting, setandan buah pinang, mayang pinang, tembakau, kasang jinem/kain, elekan, dan lain-lain semuanya mengandung makna/perlambang dalam kehidupan berumah tangga. Upacara Ngeuyeuk Seureuh dimaksudkan untuk menasihati kedua calon pengantin tentang pandangan hidup dan cara menjalankan kehidupan berumah tangga berdasarkan etika dan agama, agar bahagia dan selamat. Upacara pokok dalam adat perkawinan adalah ijab kabul atau akad nikah. Ngeuyeuk asal dari kata heuyeuk, punya dua arti yaitu :

1) Sama dengan mengatur mengurus atau mengerjakan, contoh : Ngaheuyeuk Nagara, mengurus negara, ngeuyeuk padi, ngirik padi supaya padinya jatuh dari tangkainya, biasanya kalau mau dibuat benih.

2) Mengandung makna berpegangpegang contoh : Pangheuyeukheuyeuk leungeun, papuntangpuntang leungeun, dalam mengerjakan sesuatu, tegas bekerja dengan cara bergotong royong. Ngeuyeuk Seureuh artinya mengerjakan sesuatu pekerjaan bahu membahu, saling membantu.

3) Adapun waktunya menjalankan Upacara Ngeuyeuk Seureuh biasanya malam menjelang esok untuk akad nikah. Yang melaksanakan upacara hanya perempuan saja dan sudah berumur. Pemimpin Upacara Ngeuyeuk Seureuh seorang wanita yang sudah ahli. 
Orang yang menjadi pemimpin Upacara Ngeuyeuk Seureuh, tidak perlu yang sudah berumur saja, yang penting harmonis dalam kehidupan rumah tangganya dan tidak punya prasangka buruk terhadap orang lain. Intinya ia menjadi panutan orang lain, tidak pernah melakukan hal-hal buruk atau menyimpang dalam rumah tangganya. Mungkin kalau pemimpin Upacara Ngeuyeuk Seureuh menyimpang dalam rumah tangganya, dikhawatirkan menular kepada kedua mempelai. Pemimpin Upacara Ngeuyeuk Seureuh, harus menerangkan kepada kedua calon pengantin, mana yang betul dan mana yang salah, mana yang harus dihindari dan mana yang harus dikerjakan Intinya ia harus memberi nasihat ke jalan kebenaran dalam menjalani rumah tangga. Dalam melaksanakan Upacara Ngeuyeuk Seureuh, selain ada pemimpin perempuan, hadir pula seorang laki-laki yang dianggap sesepuh, yang tugasnya hanya memimpin doa saja sebelum upacara dimulai.

Jumlah orang yang melaksanakan Upacara Ngeuyeuk Seureuh, perkalian dari 7 (tujuh), artinya kalau tidak tujuh harus empat belas, dua puluh satu atau dua puluh delapan. Laki-laki (sesepuh) yang memimpin doa tidak termasuk dalam hitungan. Tidak sembarang orang dapat mengikuti pelaksanaan upacara ini. Ada semacam pantangan bagi peserta upacara atau yang tidak diperbolehkan mengikuti upacara tersebut, yaitu perempuan sering menikah, perempuan yang sedang haid, perempuan yang sering bertengkar dengan suaminya, atau perempuan tidak pernah haid. Bahkan sekadar untuk menyaksikan pelaksanaan Upacara Ngeuyeuk
Seureuh pun mereka tidak diperbolehkan. Hal itu disebabkan adanya kekhawatiran kondisi kehidupan mereka menular kepada calon pengantin.

Tahapan-tahapan upacara yang dilakukan pemimpin upacara, pertama mengambil ajug yang berpalet 7 (tujuh) sumbu, lalu dinyalakan. Sesudah nyala, pemimpin upaca menerangkan makna atau perlambang pelita yang menyala. Pelita yang 7 (tujuh) melambangkan hari Senin sampai Minggu, sedangkan apinya melambangkan matahari, artinya kalau berumah tangga harus saling memberi pengertian, saling mengasihi. Minyak keletik kelapa hijau, melambangkan menjalani kehidupan rumah tangga harus menerima apa adanya, jangan suka bertengkar.

Selanjutnya pemimpin upacara mengambil kain kafan dan tikar, lalu menjelaskan maknanya kepada kedua calon pengantin. Bahwa manusia yang sedang berada di atas atau di bawah, yang kaya atau miskin, perempuan atau laki-laki, tua atau muda, pada akhirnya jika meninggal akan dibungkus kain kafan dan tikar pandan sampai dibawa ke pemakaman. Oleh sebab itu, janganlah menjadi orang yang sombong, angkuh, tetapi harus belajar menghargai orang lain, serta berkewajiban menjalankan perintah agama untuk bekal di akhirat nanti.

Masing-masing peserta upacara mengambil 2 (dua) lembar sirih yang dibagikan pemimpin upacara. Dari dua lembar kemudian disatukan bagian permukaan atasnya hingga bersatu, selanjutnya pinggiran daun sirih kiri dan kanan digulung sampai gulungan tersebut bertemu di tengah-tengah daun sirih dan diikat dengan benang. 
Gulungan sirih yang sudah diikat namanya lungkun, lambang kepunyaan laki-laki, benang berlambang harta benda perempuan. Artinya, mengurus atau merawat suami adalah kewajiban isteri, bukan orang tua lagi. Kewajiban isteri tersebut harus teguh, kuat dan menjadi pemikat suami dengan rasa kasih sayang.

Rambu (sisa kain potongan) harus tujuh warna, melambangkan akal dengan usahanya, dan banyak pertimbangan yang harus dipikirkan dan diperhatikan. Memang tidak bisa dianggap enteng oleh perempuan (calon isteri), kalau sudah berumah tangga harus belajar mandiri. Isteri yang sudah terikat suami harus menghadapi sendiri segala macam persoalan berumah tangga dengan tabah, sabar tawakal, sebab orang tua sudah tidak bisa lagi ikut campur dalam rumah tangga anaknya.

Pemimpin upacara mengambil dua lembar sirih. Sirih-sirih tersebut dirapatkan bagian permukaan atasnya setelah salah satu permukaan diolesi kapur sirih basah. Selanjutnya sirih dilipat berbentuk kerucut dan diisi dengan gambir, pinang dan sebagainya - sebagaimana kelengkapan yang mau menginang, terakhir ditutupi tembakau. Sirih tersebut dilambangkan sebagai kemaluan perempuan. Lungkun dan tektek bersatu dalam dua tangkai, sebab lembaran dua sirih menyatakan, bersatunya laki-laki dengan perempuan yang berbeda asalnya, artinya berbeda ibu bapaknya. dan sah untuk dinikahkan. Nginang berlambang, dalam menjalani kehidupan harus arif dan bijaksana. Intinya segala sesuatu yang akan diperbuat harus dipertimbangkan dengan matang, jangan melakukan perbuatan yang tanpa dipikirkan dahulu, karena akan mengakibatkan celaka.

Pinang yang sangat muda sekali, melambangkan kehidupan berumah tangga. Buah pinang dibelah, kelihatan isi pinang melambangkan kehidupan berumah tangga yang masih harmonis, saling memberikan kasih sayang, saling pengertian, tidak pernah cekcok, licin mirip telur mentah. Pinang yang sudah dibelah melambangkan, bahwa membangun rumah tangga pasti ada manis dan pahit, suka dan duka. Menjalani hidup harus berbaik hati, bertoleransi, jangan berprasangka buruk terhadap orang lain, dan harus selalu waspada menjalani kehidupan.

Pemimpin upacara mengambil tunjangan dan elekan, selanjutnya ia menerangkan maknanya kepada calon pengantin. Tunjangan melambangkan kepada yang berumah tangga bahwa hidup berbarengan, dan masing-masing harus jadi fondasi rumahtangga, apalagi untuk suami harus benar-benar menjadi pelindung isteri, dan isteri tidak punya perasaan gundah karena ada yang melindunginya dengan rasa tanggung jawab.

Elekan yang nantinya akan dipecahkan bersamaan dengan acara memecahkan telur mentah dalam Upacara Nincak Endog, dengan cara diinjak oleh pengantin laki-laki. Menginjak elekan melambangkan sindiran untuk manusia bahwa orang yang bodoh tidak berilmu, hidupnya selalu diinjak orang. Dengan demikian kalau menjadi orang jangan seperti elekan, harus mempunyai ilmu agar ada bekal untuk menjalani hidup.

Ibarat endog (telur) yang sudah dipecahkan akan kelihatan airnya yang 
kental. Artinya, endog diibaratkan rahim dan air yang kental adalah sperma laki-laki. Jadi, dalam rahim sudah ada calon janin. Pemimpin upacara memberi nasihat kepada calon pengantin, bahwa kalau jadi manusia janganlah sombong dan angkuh. Pada dasarnya manusia sama, dilahirkan dari rahim ibu, jadi apa yang mau disombongkan oleh manusia.

Air dalam kendi atau kele. Air itu sifatnya dingin serta suka digunakan untuk membersihkan. Dalam Upacara Nincak Endog, setelah pengantin laki-laki menginjak elekan dengan kaki kanan dan menginjak telur dengan kaki kiri, kakinya kemudian dibasuh dengan air yang ada di dalam kele oleh pengantin perempuan. Selesai membasuh kaki, kendi kemudian dijatuhkan oleh kedua pengantin hingga remuk. Membasuh kaki memberi arti memperlihatkan kesetiaan isteri kepada suami. Dan makna lainnya, kalau kita bertamu ke rumah orang lain jangan membawa itikad buruk, hati kusut, sebaliknya harus gembira dan bersih hati. Andaikan ada masalah dalam rumah tangga harus dipecahkan atau diselesaikan bersamasama dengan pikiran yang dingin, ibarat kendi yang berisi air dijatuhkan sampai pecah.

Harupat sifatnya getas 'mudah patah', kalau patah sekaligus. Manusia ada yang sifatnya seperti itu dan disebut getas harupateun, yaitu sifat berangasan dan cepat tersinggung. Oleh karena itu sebelum memecahkan kendi, harupat oleh pengantin perempuan dinyalakan dengan menggunakan api pelita. Kemudian nyala api dimatikan dengan cara dimasukkan ke dalam kendi berisi air, selanjutnya dibuang. Prosesi itu melambangkan ibarat membuang tabiat getas harupateun yang harus dijauhi dalam menata rumah tangga. Sebaliknya sebelum bertindak kita harus berpikir matang dulu, seperti yang sedang menginang, sarinya dimakan ampasnya dibuang.

Batu pipisan lengkap dengan batu penggilasannya (lelaki), yaitu alat untuk meramu obat-obatan supaya lembut, artinya kalau suami isteri di rumah harus berkata lemah lembut, hindari ucapan yang kasar atau mengundang amarah. Batu pipisan sangat kuat, bahkan diinjak pun tidak akan pecah, ini melambangkan bahwa kita berada di dunia harus punya pegangan hidup yang kuat dan teguh. Dalam Upacara Nincak Endog, menginjak telurnya harus di atas batu pipisan.

Bokor berisi beras putih, tektek, lepit, uang, kunyit yang sudah diiris, dan macam-macam kembang 'bunga', itu memberi nasihat kepada semua khususnya yang mau membangun rumah tangga, jangan lupa syiar atau ikhtiar untuk bekal hidup. Beras mengandung arti bahwa kita harus mau bertani untuk makan, tektek dengan lepit artinya harus mau berdagang, sedangkan syiar uang dilambangkan uang dengan cara berusaha. Kalau bisa sampai kaya raya, harta yang melimpah. Warna kunyit melambangkan, nama kita jangan sampai jelek di hadapan orang lain, akan tetapi harus wangi seperti kembang. Bokor beserta isi fungsinya untuk nyawer. Dalam nyawer ditaburkan beras putih, uang kecil, dan irisan kunyit ke segala penjuru, hal ini mengandung arti kalau hidup sudah serba berkecukupan jangan berfoya-foya, tapi bantulah sanak saudara yang memerlukan bantuan. 
Bokor diisi air dengan kembang tujuh warna. Usai Upacara Ngeuyeuk Seureuh, air dalam bokor yang sudah didoai digunakan untuk mandi oleh calon pengantin perempuan. Dengan harapan, jika calon pengantin perempuan sudah dimandikan, wajahnya akan bercahaya, membuat orang terpesona, seperti orang melihat kembang.

Ayakan atau sair, memberi nasihat kepada calon pengantin, bahwa dalam menjalani hidup harus seperti ayakan, bisa memisahkan mana yang kasar dan yang halus. Demikian juga dengan kita, jika mau berbuat sesuatu harus dipikir dahulu dengan matang agar hasilnya tidak merugikan.

Cecempeh atau nyiru kecil, fungsinya untuk napi beas 'membersihkan beras'. Maknanya hampir sama dengan ayakan, yaitu kalau berbuat sesuatu jangan gegabah, karena tidak dipikirkan dahulu akan menyesal nantinya. Adapun kita dibaratkan sedang napi beas, memisahkan mana beras dan mana gabah, maka intinya berbuat sesuatu harus dipikir dahulu dengan cermat.

Suluh dengan ikatan daun, itu juga memberi nasihat kepada calon pengantin, kalau nanti menjalani rumah tangga di antara salah satu ada masalah, baik dari isteri maupun suami, jangan sekali-kali membawa orang lain apalagi orang tua ke dalam masalah tersebut.

Selanjutnya Pemimpin Upacara Ngeuyeuk Seureuh mengangkat alu, dengan maksud mau menggebrak calon pengantin. Calon pengantin perempuan dan laki-laki disuruh mengambil barang-barang yang ada di bawah kain kafan tersebut, namun harus sedapatnya tidak boleh memilih. Upacara
Ngeuyeuk Seureuh selesai dan ditutup dengan pembacaan doa.

\section{c. Seserahan}

Seserahan yaitu menyerahkan si jejaka, calon pengantin laki-laki kepada calon mertuanya untuk dinikahkan dengan si gadis. Pada acara ini biasa dihadiri oleh para kerabat terdekat, di samping menyerahkan calon pengantin laki-laki juga barang-barang berupa uang, pakaian, perhiasan, sandal, sepatu, tas, komestik, dan perlengkapan wanita, dalam hal ini bergantung pula pada kemampuan pihak calon pengantin laki-laki. Upacara ini dilakukan satu atau dua hari sebelum hari pernikahan atau ada pula yang melaksanakannya pada hari pernikahan, sebelum akad nikah.

Seserahan sama dengan menyerahkan, yaitu menyerahkan calon pengantin laki-laki kepada orang tua calon pengantin perempuan. Dinamakan demikian, sebab harus ada seserahan atau menyerahkan dari pihak keluarga calon pengantin laki-laki ke pihak keluarga calon pengantin perempuan. Adapun yang memiliki hak menikahkan adalah orang tua calon pengantin perempuan, dan yang berhak melaksanakan upacara pernikahan yaitu orang tua calon pengantin perempuan, bukan orang tua calon pengantin lakilaki. Mengenai waktu Upacara Seserahan dilaksanakan, sebelum Upacara Ngeuyeuk Seureuh, sebab dalam Upacara Ngeuyeuk Seureuh kedua calon pengantin harus berdampingan. Sementara itu dalam upacara tersebut perlambangnya adalah memberi nasihat kepada kedua calon pengantin yang akan menjalani kehidupan berumah tangga. Atau sehari sebelum upacara Akad Nikah di- 
laksanakan. Dalam upacara seserahan, calon pengantin laki-laki paling depan didampingi orang tua dan keluarganya, dan rombongan yang mengantar mengikuti dari belakang sambil membawa barang-barang bawaan calon pengantin laki-laki. Barang-barang tersebut dihias sedemikian rupa. Barang-barang yang dibawa calon pengantin laki-laki antara lain, perhiasan, uang, alat-alat shalat, pakaian, dan lain-lain. Barang-barang tersebut, yang dibawa pengantin lakilaki, untuk bekal dikala sudah menikah resmi menjadi suami isteri, dan membangun rumah tangganya tidak bingung karena sudah dipersiapkan sebelumnya.

Setibanya di rumah calon mertua, calon pengantin laki-laki disambut oleh keluarga calon mertua, dan dipersilahkan masuk ke dalam rumah. Setelah calon pengantin beserta orang tuanya masuk dengan diikuti rombongan yang membawa barangbarang, mereka dipersilahkan untuk duduk. Setelah berkumpul, orang tua calon pengantin laki-laki melalui wakil atau sesepuh sebagai juru bicara yang sudah ahli dalam bidang Upacara Seserahan, mengutarakan maksud dan tujuannya.

Juru bicara Upacara Seserahan mengutarakan mewakili orang tua calon pengantin laki-laki, dengan maksud akan menyerahkan calon pengantin laki-laki, dan orang tua calon perempuan diharapkan menerimanya. Orang tua pengantin perempuan, melalui juru bicaranya yaitu sesepuh yang ahli dalam bidang Upacara Seserahan, mengatakan menerima atas penyerahan calon pengantin laki-laki. Sesudah serah terima selesai, barangbarang yang dibawa oleh rombongan calon pengantin laki-laki, secara simbolik diterima oleh pihak keluarga pengantin perempuan. Selanjutnya barang-barang tersebut diestafetkan, disimpan di kamar calon pengantin perempuan. Upacara Seserahan selesai ditutup dengan membacakan doa untuk kedua calon pengantin, agar diberi keselamatan dengan dipimpin oleh sesepuh.

\section{Upacara Akad Nikah}

Upacara pernikahan dapat dilaksanakan apabila telah memenuhi ketentuan-ketentuan yang telah digariskan dalam agama Islam dan adat. Ketentuan tersebut adalah: adanya keinginan dari kedua calon mempelai tanpa paksaan, harus ada wali nikah yaitu ayah calon mempelai perempuan atau wakilnya yang sah, ada ijab kabul, ada saksi, dan ada mas kawin. Yang memimpin pelaksanaan akad nikah adalah seorang Penghulu atau Naib, yaitu pejabat Kantor Urusan Agama.

Upacara Akad Nikah biasa dilaksanakan di mesjid atau di rumah mempelai wanita. Adapun pelaksanaannya adalah kedua mempelai duduk bersanding diapit oleh orang tua kedua mempelai. Mereka duduk berhadapan dengan penghulu yang di kanan kirinya didampingi oleh 2 orang saksi. Adapun para undangan duduk berkeliling. Yang mengawinkan harus wali dari mempelai perempuan atau mewakilkan kepada penghulu.

Kalimat "menikahkan" dari penghulu disebut ijab, sedang sambutan dari mempelai pria disebut qobul (kabul). Setelah dilakukan ijabqobul dengan baik selanjutnya mempelai pria membacakan talek, yang bermakna 'janji' dan menandatangani surat nikah. Upacara diakhiri dengan 
penyerahan mas kawin dari mempelai pria kepada mempelai wanita.

Sebelum pelaksanaan Upacara Akad Nikah dimulai, biasanya calon pengantin laki-laki menunggu ditempat yang berbeda namun tidak jauh dari kediaman calon pengantin perempuan. Ketika akad nikah akan dimulai, baru keluarga calon pengantin isteri mengutus salah seorang untuk menjemput pengantin laki-laki. Calon pengantin laki-laki beserta para pengiring menuju kediaman calon pengantin perempuan. Setelah tiba disambut acara Mapag Panganten dipimpin oleh penari yang disebut Mang Lengser. Calon pengantin lakilaki disambut oleh ibu calon pengantin perempuan dengan mengalungkan rangkaian bunga.

Tempat pelaksanaan Upacara Akad Nikah, biasanya di mesjid, tengah rumah, atau halaman rumah. Di tempat Upacara Akad Nikah tersebut sudah disediakan meja dan kursi untuk duduk kedua pengantin, begitu juga kursi untuk orang tua kedua pengantin, Penghulu, dan Saksi.

Manakala prosesi Upacara Akad Nikah akan dimulai, di tempat pelaksanaan acara tersebut sudah berkumpul petugas KUA, para saksi, dan pengantin pria. Kedua orang tua menjemput pengantin perempuan dari kamar, lalu didudukkan di sebelah kiri pengantin pria dan dikerudungi dengan tiung panjang, artinya penyatuan dua insan yang masih murni. Waktu akad nikah akan dimulai, keadaan harus hening, khidmat, tidak boleh ada yang bersuara atau ribut. Akad Nikah dimulai pukul 08.00 atau 09.00. Kerudung baru dibuka saat kedua mempelai akan menandatangani surat nikah.

Akad Nikah selesai, kemudian ditutup dengan pembacaaan doa dipimpin oleh Penghulu, dilanjutkan dengan acara sungkeman oleh kedua pengantin. Kedua pengantin meminta doa restu dan nasihat agar dalam menjalani kehidupan berumah tangga mendapat ridho dari Allah SWT. kepada kedua orang tua masing-masing dengan disaksikan oleh Penghulu dan keluarga kedua belah pihak. Sungkeman pertama dilakukan kepada orang tua pengantin perempuan.

\section{Upacara Adat Sesudah Akad Nikah}

Setelah selesai acara pokok yaitu Upacara Akad Nikah, masih ada upacara-upacara yang biasa dilakukan oleh masyarakat di Kabupaten Bandung. Upacara-upacara tersebut antara lain, yaitu :

\section{a. Munjungan/Sungkeman}

Munjungan atau sungkem yaitu kedua mempelai sungkem kepada kedua orang tua mempelai untuk memohon doa restu.

\section{b. Upacara Nincak Endog}

Upacara Nincak Endog atau Upacara Injak Telur dilaksanakan setelah Upacara Nyawer. Kedua mempelai mendekati tangga rumah, di sana telah tersedia perlengkapan seperti sebuah ajug/lilin, seikat harupat (sagar enau) berisikan 7 batang, sebuah tunjangan atau barera (alat tenun tradisional) yang diikat kain tenun poleng, sebuah elekan, sebutir telur ayam mentah, sebuah kendi berisi air, dan batu pipisan. Semua perlengkapan ini mempunyai perlambang. Dalam 
pelaksanaannya, lilin dinyalakan, kemudian mempelai wanita membakar ujung harupat dan memadamkannya dengan memasukkan harupat ke dalam kendi berisi air dan langsung dibuang. Prosesi dilanjutkan, mempelai pria menginjak telur, setelah itu kakinya diletakkan di atas batu pipisan untuk dibasuh dengan air kendi oleh mempelai wanita dan kendinya langsung dihempaskan kedua mempelai ke tanah hingga hancur. Makna dari upacara ini adalah menggambarkan pengabdian seorang istri kepada suaminya. Andaikan ada masalah dalam rumah tangga harus dipecahkan atau diselesaikan bersama-sama dengan pikiran yang dingin, ibarat kendi yang berisi air dijatuhkan sampai pecah.

\section{c. Upacara Buka Pintu}

Pelaksanaan Upacara Buka Pintu, dilakukan setelah Upacara Nincak Endog. Mempelai wanita masuk ke dalam rumah, sedangkan mempelai pria menunggu di luar. Hal itu menunjukkan bahwa mempelai wanita belum mau membukakan pintu sebelum mempelai pria kedengaran mengucapkan syahadat. Maksud upacara ini untuk meyakinkan kebenarannya beragama Islam. Setelah membacakan syahadat, pintu dibuka dan mempelai pria dipersilakan masuk. Tanya jawab antara keduanya dilakukan dengan nyanyian (tembang) yang dilakukan oleh juru tembang. Adapun puisi Buka Pintu dalam bahasa Sunda adalah sebagai berikut :

\section{Istri :}

Saha eta anu kumawani

Taya tata taya bemakrama

Ketrak-ketrok kana panto

Pameget :
Geuning bet jadi kitu

Api-api kawas nu pangling

Apan ieu teh engkang

Hayang geura tepung

Tambah teu kuat ku era

Da di luar seueur tamu nu ningali Istri :

Euleuh kalah panutan

Panyana teh lalaki cilimit

Anu bade ngagoda ngadoja

Pameget:

Enggal atuh buka panto Istri:

Mangga nanging panuhun

Mugi engkang titi tur rintih

Rayi rek naros heula

Pameget:

Aduh Eulis ampun

Jadi atuh diri kakang

Ku nyai teh meureun rek diuji deui

Mangga kumaha kersa

Mung pamugi ulah sesah teuing

Bisi kakang teu bisa ngajawab Istri:

Patarosan henteu abot

Mung mugi ulah bendu

Pangnerangkeun masing taliti

Hartosna pamajikan

Mangga mung sakitu

Pameget:

Aduh tobat geuning beurat

Panyana teh rek diuji elmu pasti

Atawa elmu pisah

Pamajikan asal kecap majik

Tempat matuh salila ngumbara

Ngumbara di alam rame

Ti awit engkang emut

Tug nepi ka ngemasing pati

Lunta ti marcapada

Majik sarta matuh

Tempatna di pamajikan

Tempat majik ati rawuh sanubari

Waruga katut rasa

Tempat majik kasuka kasedih

Tempat majik banda pangaboga 
Nyaah asih katut sono

Nyanggakeun mung sakitu Istri:

Euleuh nyata surti raspati Rai teh bingah pisan

Pameget:

Saupami kitu

Enggal atuh geura buka

Ieu kakang heunteu kaduga ku isin Isin dilalajoan Istri:

$\mathrm{Nu}$ raspati tangtos titi rintih Manah jembar pamolahna sabar Walereun teh aya keneh

Ku margi tacan tutug

Tacan dugi kana ngahiji

Ucap sinareng lampah Pameget:

Geura ituh kitu

Eulis mah ku merekela

Nanging mangga rek naroskeun naon deui

Kakang seja ngiringan Istri:

Kasauran waleran nu tadi

Naha bukti sareng kanyataan

Atawa mung jangji bae

Mun saur tanpa bukur

Lir pasini nu tara jadi

Elmu teu jeung amalna

Nuhun engkang nuhun

Kateda kalingga murda

Mangga lebet ditampi ku ati wening

Ku rasa anu setra

\section{d. Upacara Huap Lingkung}

Setelah Upacara Buka Pintu selesai kedua pengantin dipertemukan, lalu dibawa ke kamar pengantin. Di kamar sudah disediakan aneka macam makanan yang sudah dihias sedemikian rupa. Kedua mempelai duduk bersanding, yang wanita di sebelah kiri pria, di depan mempelai telah tersedia adep-adep, yaitu nasi kuning dan bakakak ayam (panggang ayam yang bagian dadanya dibelah dua). Mulamula bakakak ayam dipegang kedua mempelai lalu saling menarik hingga menjadi dua. Siapa yang mendapatkan bagian terbesar, dialah yang akan memperoleh rejeki besar di antara keduanya. Setelah itu kedua mempelai melakukan prosesi Huap Lingkung, saling menyuapi. Upacara ini dimaksudkan agar kedua mempelai harus saling memberi tanpa batas, dengan tulus dan ikhlas sepenuh hati.

Selesai Upacara Huap Lingkung, kedua mempelai dipersilakan duduk di pelaminan, diapit oleh kedua orang tua mempelai untuk menerima ucapan selamat dari para undangan (acara resepsi).

\section{e. Upacara Sawer}

Selesai Upacara Sungkeman atau Munjungan dilanjutkan dengan Upacara Nyawer. Adapun perlengkapan yang diperlukan dalam Upacara Sawer (Nyawer): adalah sebuah bokor yang berisi beras kuning, uang kecil (receh) /logam, bunga, dua buah tektek (lipatan sirih yang berisi ramuan untuk menyirih), dan permen. Pada pelaksanaannya kedua mempelai duduk di halaman rumah, di bawah cucuran atap (panyaweran), upacara dipimpin oleh juru sawer. Juru sawer menaburkan isi bokor tadi kepada kedua pengantin dan para undangan sebagai selingan dari syair yang dinyanyikan olehnya sendiri. Adapun makna dari upacara nyawer tersurat dalam syair yang ditembangkan juru sawer, intinya adalah memberikan nasihat kepada kedua mempelai agar saling mengasihani, dan mendoakan agar kedua mempelai mendapatkan 
kesejahteraan dan kebahagiaan dalam membina rumah tangganya, hidup rukun sampai diakhir hayatnya.

Nyawer asal kata dari "awer" yaitu barang encer yang tumpah. Bahasa "panyaweran" artinya tempat turunnya air dari genting yang tempatnya di depan halaman rumah. Dalam Upacara Sawer, "nyawer" pengantin dalam upacara perkawinan dilaksanakan di panyaweran atau tepas rumah yang biasa kasaweran atau terkena air hujan yang terbawa hembusan angin.

Upacara Sawer Pengantin dipimpin oleh Juru Sawer, yang melakukannya adalah seniman atau orang yang mahir menyanyi kawih dan tembang Sunda. Tentu saja syarat lannya harus paham dan hapal betul seluk beluk makna dan filosofi dari setiap kata dan kalimat puisi sawer serta barang-barang yang disawerkan.

Adapun barang-barang yang akan disawerkan yaitu beras, kunir, uang logam dan sebagainya disatukan dan ditempatkan dalam bokor. Dilihat dari isi bokor tersebut semuanya mengandung siloka, maknanya diutarakan melalui kidung sawer yang dibawakan oleh Juru Sawer. Maksud dan tujuan isi sawer, intinya memberikan nasihat kepada kedua pengantin.

Ritual Sawer Pengantin merupakan bagian dari rangkaian upacara perkawinan di Tatar Sunda. Secara garis besar rangkaian upacara perkawinan di Tatar Sunda yang saat ini kerap dilaksanakan terbagi menjadi dua, yaitu pra dan pascapernikahan. Upacara Nyawer biasanya dilaksanakan setelah selesai Akad Nikah. Adapun Puisi sawer dalam bahasa Sunda :
Asmarandana

Rehna Ujang geus ririmbit Saena jadi rarambat

Manah ulah rumbat-rambet

Bisi matak henteu kebat

Duriat gancang pegat

Ieu ku bapa disebut

Jalanna awet duriat

$K u$ lantaran geus rarabi

Sagala kudu kasaba

Jalan anu matak rebo

Dipalar bias balaba

Tina sagala loba

Seueur rencang loba babu Da geus boga nu dipurba

Salawasna kudu rintih

Lamun ngeunaan papatah

Istri teh masingna atoh

Ulah nepi ka ngabantah

Poma ulah awuntah

Genteng-genteng ulah runtuh

Kurenan sing betah

Lalaki sing taki-taki

Da meunang papada suka

Tur meunang hese beleke

Lalaki teu kenging murka

Sumawon mun codeka

Milampah awon ngabaku

$\mathrm{Nu}$ kitu deukeut cilaka

Lamun Ujang aya rijki

Sumawon hese beleke

Bisi aya anu nyangka

Barang beunang culika

Pajah urang serong laku

Tungtungna jadi cilaka

Ujang sing gede kainggis 
Ulah getas ulah gangah

Komo mun sok poporongos

Was-was matak mawa tiwas

Ulah sok haying puas

Adat kitu gancang pupus

Sagala babari panas

Tegesna Ujang sing eling

Bapa the beak nya melang

Kade Ujang ulah meleng

Polah kitu masing ilang

Inget ieu piwulang

Leuheung mun ruing mungpulung

Ku Bapa mindeng kalanglang

Bahan dan alat-alat yang digunakan dalam Upacara Saweran adalah sebagai berikut :

1) Beras putih. Simbol atau makna dari beras putih adalah: ketentraman dalam sebuah keluarga salah satu syaratnya adalah cadangan pangan yang aman. Untuk masyarakat Sunda cadangan pangan yang pertama dan utama adalah padi atau beras. Bila telah meraih itu semua, keluarga Sunda tersebut dengan sendirinya akan merasakan peribahasa sapapait samamanis, dan akhinya akan tercipta ketenangan dalam rumah tangga.

2) Leupit. Simbol atau makna dari leupit adalah : Leupit adalah sirih yang dilipat segi tiga di dalamnya berisi kapur sirih, gambir, pinang, kapol, saga, dan tembakau. Leupit mempunyai makna kehidupan dalam rumah tangga harus terbuka, baik suami terhadap isteri maupun sebaliknya, maksud terbuka di sini adalah penghasilan pekerjaan harus saling mengetahui. Sedang rasa leupit kalau dikunyah ada rasa pahit, manis, melambangkan bahwa menjalani rumah tangga tidak selalu manis ada pahitnya.

3) Kunyit. Simbol atau makna dari kunyit yaitu : kunyit adalah bumbu dapur yang berwarna kuning. Kuning adalah lambang dari emas. Maksudnya agar rumah tangga calon pengantin dihargai oleh orang lain, seperti kita yang menghargai mahalnya nilai emas.

4) Uang logam. Makna atau simbol dari uang logam yaitu : uang logam (uang receh) adalah lambang dunia atau kekayaan. Hidup di dunia harus mempunyai semangat. Oleh karena itu, mencari kekayaan dalam wujud materi layaknya kita akan hidup di dunia untuk selamanya, serta menyiapkan bekal akhirat layaknya kita akan mati hari esok.

5) Permen. Simbol atau makna dari permen yaitu : umumnya rasa permen adalah manis. Oleh karena itu dalam rumah tangga harus diwarnai oleh pemanis atau didasari keharmonisan keluarga yang luwes, tidak monoton, penuh inovasi, dan fungsi keluarga sesuai dengan harapan, yaitu menggapai kebahagian. Caranya, antara suami dan istri saling menyayangi, tidak gampang tersulut nafsu. Bahkan, bila perlu, lebih baik mengalah ketimbang menyemai bibit pertikaian.

Sebelum Upacara Nyawer dilaksanakan, terlebih dahulu disiapkan kursi untuk duduk kedua pengantin, dan satu orang ditugaskan untuk memegang payung. Payung untuk 
melindungi kepala kedua pengantin dari barang-barang saweran yang bertaburan. Payung ini berwarna kuning disebut payung agung dan mempunyai makna. Maknanya diharapkan kedua pengantin dapat menjadi pengayom atau pelindung bagi orang lain.

Selanjutnya Juru Sawer menyiapkan bahan-bahan dan alat-alat saweran. Kemudian mempersilakan pengantin untuk duduk di kursi yang sudah disiapkan dan disaksikan oleh kedua belah pihak orang tuanya. Kemudian Juru Sawer menerangkan makna dan tujuan dari pelaksanaan Upacara Saweran. Sebelum acara dimulai terlebih dahulu Juru Sawer memanjatkan doa agar mendapat ridho dari Tuhan Yang Mahaesa.

\section{f) Meuleum Harupat}

Pengantin perempuan mengambil harupat yang sudah disediakan, kemudian dibakar dengan lilin yang sudah menyala. Ujung harupat yang menyala kemudian dimatikan dengan ujung jari dan dipatahkan serta dilemparkan ke luar. Prosesi membakar harupat dan dimatikan memberikan arti, bahwa manusia jangan memiliki sifat seperti harupat, yang getas 'kalau patah sekaligus'. Manusia ada yang sifatnya begitu, yang disebut getas harupateun, yaitu sifat berangasan dan cepat tersinggung. Oleh karena itu membuang harupat dilakukan sebelum memecahkan kendi. Pengantin perempuan menyalakan harupat dengan api pelita, sesudah nyala dimatikan terus dibuang. Hal itu melambangkan membuang tabiat getas harupateun yang harus dijauhi dalam menata rumah tangga. Sebaliknya, sebelum bertindak kita harus berpikir matang dulu, seperti ketika menginang, sarinya dimakan ampasnya dibuang.

\section{g) Ngalengkahan Pakara}

Pakara atau perabot ninun (elekan juga perabot ninun) dengan yang lainnya seperti, suri kincir, dan barera sudah dipersiapkan untuk prosesi Ngalengkahan Pakara. Selanjutnya tikar yang sudah digelar dan dilapisi kain panjang disusun suri kincir dan barera, kemudian ditutup kain putih. Susunan tersebut dilangkahi oleh kedua pengantin. Acara Ngalengkahan Pakara selesai, tikar dan kain panjang beserta barang lainnya yang disusun, diberikan kepada pemandu acara tersebut.

\section{h) Upacara Munduh Mantu}

Upacara Munduh Mantu pada umumnya dilaksanakan di keluarga pengantin laki-laki. Tujuannya adalah untuk memanjatkan puji syukur kepada Tuhan Yang Mahaesa, bahwa anaknya telah resmi dinikahkan dengan selamat. Selain itu juga ingin memperkenalkan menantunya lebih dekat kepada sanak familinya, yang tidak sempat hadir waktu merayakan pernikahan anaknya.

Upacara Munduh Mantu hampir sama pelaksanaannya dengan upacara pernikahan, hanya saja dalam pelaksanaan Upacara Munduh Mantu, tidak ada Upacara Nyawer, Buka Pintu, atau sebagaimana yang dilaksanakan waktu upacara pernikahan. Kemiripan antara upacara pernikahan dan upacara Munduh Mantu, dalam pelaksanaannya, pihak keluarga pengantin laki-laki mengundang sanak saudaranya atau famili, tetangga, dan para sesepuh. Seperti biasa, dalam pelaksanaan Upacara Munduh Mantu pihak keluarga pengantin laki-laki, mewakil- 
kan kepada sesepuh sebagai juru bicara yang sudah ahli di bidang acara tersebut.

Pelaksanaan Upacara Munduh Mantu biasanya dilaksanakan sesudah beberapa hari setelah upacara pernikahan dilaksanakan. Orang tua pengantin laki-laki, mengundang orang tua pengantin perempuan atau besan dengan keluarganya, untuk berkumpul bersama dalam melaksanakan Upacara Munduh Mantu. Dalam upacara ini diadakan sungkeman, kedua pengantin sungkem kepada kedua orang tua, dan kepada kedua belah pihak keluarganya juga kepada para tamu undangan.

Upacara Munduh Mantu selesai, orang tua pengantin laki-laki memanjatkan doa untuk anak dan menantunya, agar menjalani bahtera rumah tangganya selalu dilindungi Tuhan Yang Mahaesa. Seorang sesepuh memimpin doa untuk keselamatan kedua pengantin.

\section{i) Munjungan/Sungkeman}

Setelah diadakan Upacara Munduh Mantu, kedua pengantin mengadakan munjungan, yang dikunjungi adalah sanak saudaranya, baik dari pihak pria maupun pihak perempuan. Maksud kunjungan tersebut adalah untuk menyampaikan ucapan terima kasih atas bantuan mereka selama acara perkawinan berlangsung. Biasanya sambil berkunjung kedua mempelai membawa nasi dengan lauk pauknya. Usai beramah tamah, ketika kedua mempelai berpamitan akan pulang, maka pihak keluarga yang dikunjungi memberikan hadiah seperti peralatan untuk keperluan rumah tangga mereka.

\section{PENUTUP}

Masyarakat Sunda, khususnya yang ada di daerah penelitian, Kecamatan Cicalengka, Kabupaten Bandung menyebutkan tujuan dari perkawinan atau berkeluarga bagi mereka adalah karena ingin hidup bersama dengan tambatan hati, membentuk suatu wadah rumah tangga yang sakinah, mawadah, dan warahmah, mengembangkan dan membina kerukunan yang saleh, ingin sejahtera, dan tentunya untuk melaksanakan ibadah yang disunahkan Rasul.

Membentuk rumah tangga yang sakinah, mawahdah, dan warahmah adalah dambaan bagi setiap keluarga muslim. Sakinah adalah hidup berkeluarga dalam suasana yang tenang dan tenteram. Dalam mewujudkan kehidupan keluarga yang demikian dibutuhkan 3 (tiga) S, yaitu Silih Asah, Silih Asih, dan Silih Asuh. Demikian ketiga $S$ tersebut, pada umumnya diakui oleh masyarakat di Kecamatan Cicalengka, Kabupaten Bandung. Untuk mewujudkannya mereka berupaya membina, menciptakan, dan menata ketiga $S$ tersebut.

Perkawinan merupakan suatu hal yang sakral, oleh karena itu saking sakralnya untuk memutuskan masuk ke gerbang perkawinan dituntut keseriusan, hati yang mantap, dan penuh keyakinan, tidak main-main atau asal-asalan. Mereka menyadari bahwa perkawinan adalah suatu proses kehidupan sesudah kelahiran dan sebelum kematian, yang diharapkan terjadi cukup sekali dalam seumur hidupnya.

Berdasarkan kenyataan tentang upacara-upacara tradisional, khusunya 
Upacara Perkawinan Adat Sunda di Kecamatan Cicalengka, Kabupaten Bandung, maka sebagai penutup dikemukakan beberapa saran sebagai berikut :

1. Upacara Perkawinan Adat Sunda dan upacara-upacara tradisional pada umumnya memiliki nilai-nilai budaya luhur yang merupakan hakikat upacara yang dinyatakan melalui simbol-simbol upacara. Oleh karena itu upacara-upacara tradisional tersebut perlu dilestarikan, dibina dan dikembangkan.

2. Keberadaan upacara perkawinan khususnya, dan upacara-upacara tradisional pada umumnya memiliki kedudukan yang sangat penting di dalam kehidupan masyarakat di Kecamatan Cicalengka, Kabupaten Bandung. Oleh karena itu keberadaannya perlu dipertahankan.

\section{DAFTAR PUSTAKA}

Ihromi, T.O 1980.

Pokok-pokok

Budaya. Jakarta : Gramedia

Koentjaraningrat. 1980.

Pengantar Ilmu Antropologi.

Jakarta: Aksara Baru.
Muchtar, R. H. Uton, 1994.

Modana. Bandung : PT Mangle Panglipur.

Soeganda, R.Akip Prawira, 1982.

Upacara Adat di Pasundan.

Bandung : Sumur Bandung.

Suhamihardja, A. Suhandi, Dkk. 1993/ 1994.

Fungsi Upacara Tradisional pada Masyarakat Pendukungnya Masa Kini di Jawa Barat. Departemen Pendidikan dan Kebudayaan Direktorat Jenderal Kebudayaan Direktorat Sejarah dan Nilai Tradisional Proyek Penelitian Pengkajian dan Pembinaan Nilai-nilai Budaya Jawa Barat.

Warnaen, Suwarsih, 1987.

Pandangan Hidup Orang Sunda Seperti Tercermin dalam Tradisi Lisan dan Sastra Sunda. Departemen Pendidikan dan Kebudayaan Direktorat Jenderal Kebudayaan Bagian Proyek Penelitian dan Pengkajian Kebudayaan Sunda Bandung. 